地質学雑誌 Vol. 112, No. 1,2006

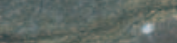

20

(1)

関東平野の基盤岩類

\title{
Basement rocks below the Kanto Plain
}

2005 年 4 月 6 日受付, 2005 年 9 月 2 日受理

C. 早稲田大学教育 ·総合科学学術院 Waseda Univ. Tokyo, 169-8050 Japan

** 島根大学総合理工学部 Shimane University, Matsue, Shimane, 690-8504

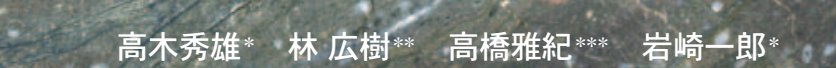
Hideo Takagi*, Hiroki Hayashi **, Masaki Takahăshi **** and

Japan . .

産業技術総合研究所 AIST, Tsukuba, Ibaraki, 305-8567 Japan

. Corresponding anthor; H. Takagi, hideo@waseda.jp

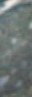

岩梘観測井さざくろ石トーナル岩マイロナイト.

関東平野の基盤岩類コアの面構造の傾斜方向に平行に切断した縦断研磨片写真とコア深度および岩相．各々のコアの位置，記載は本特

集号を参照．松伏坑井は，石油資源開発（株）提供，それ以外の観測井コアはすべて防災科学技術研究所提供，スケール: $1 \mathrm{~cm}$

筑波変成岩

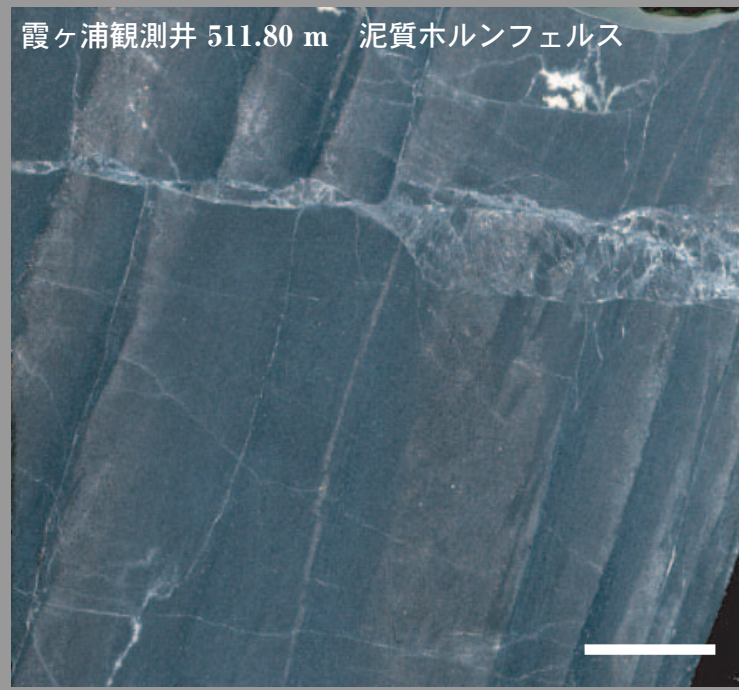

領家帯

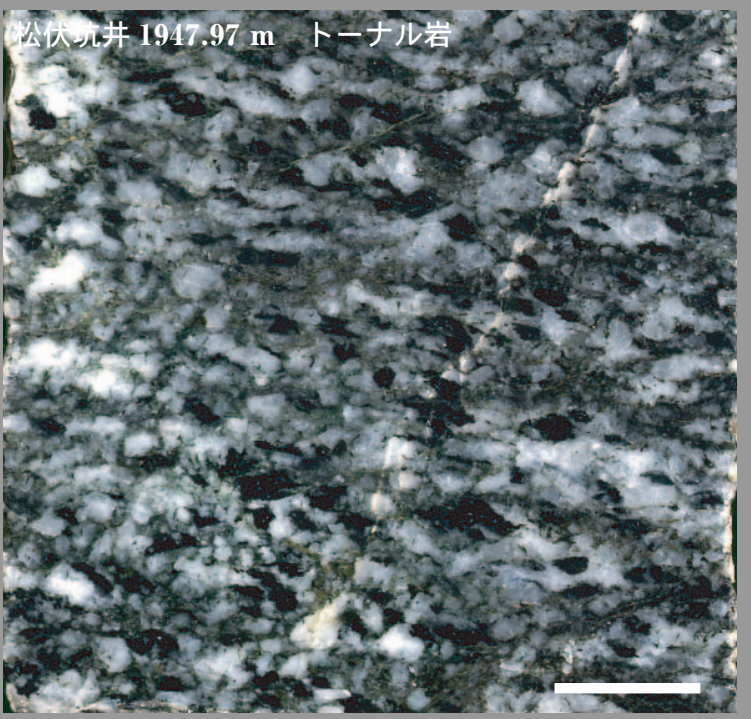

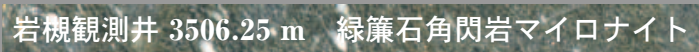

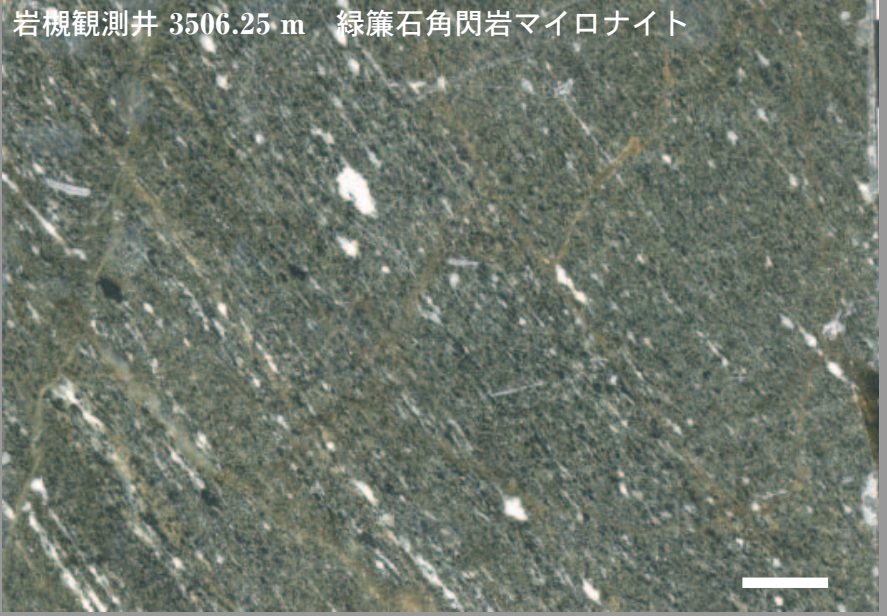

秩父帯

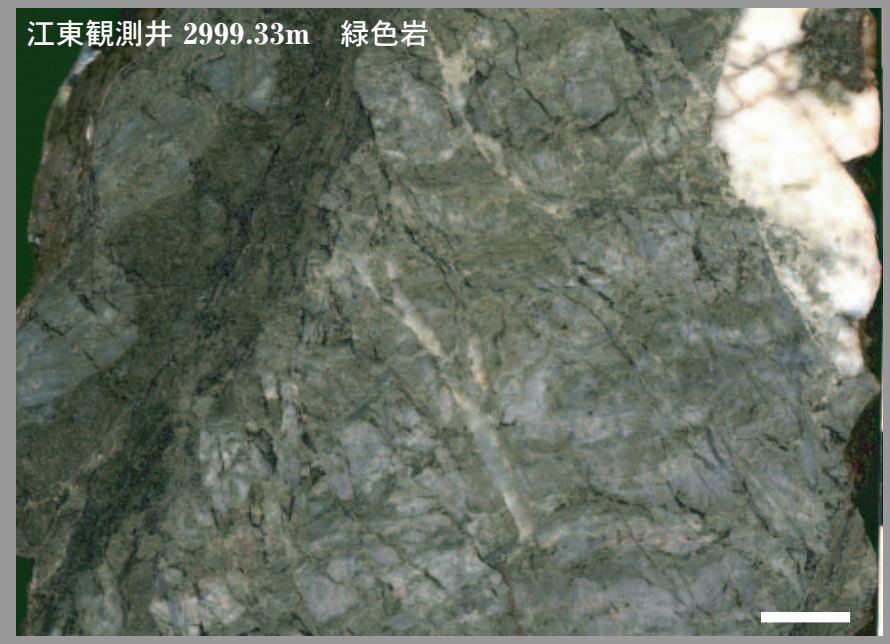

三波川帯

成田観測井 $1315.18 \mathrm{~m}$ 緑色片岩
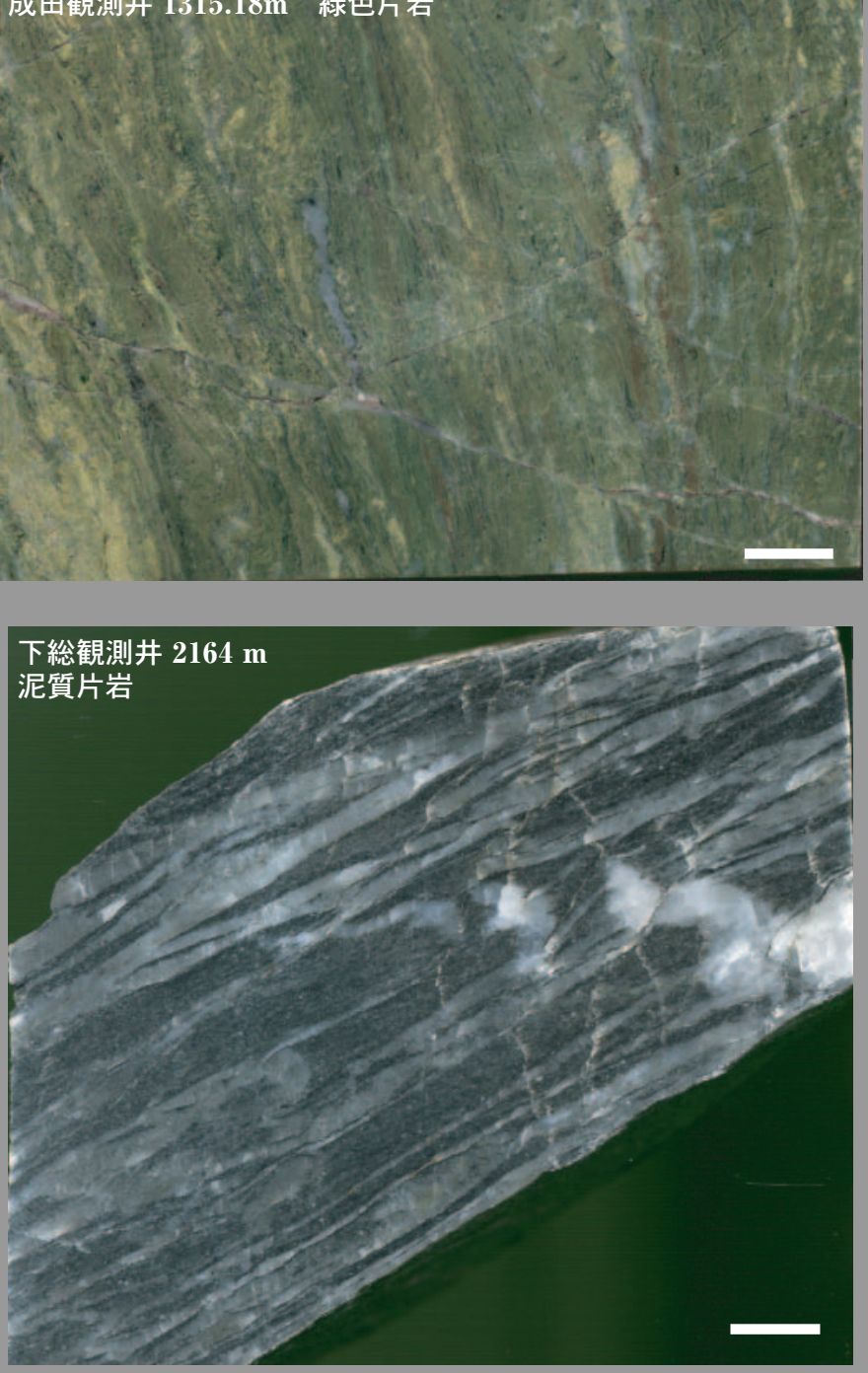